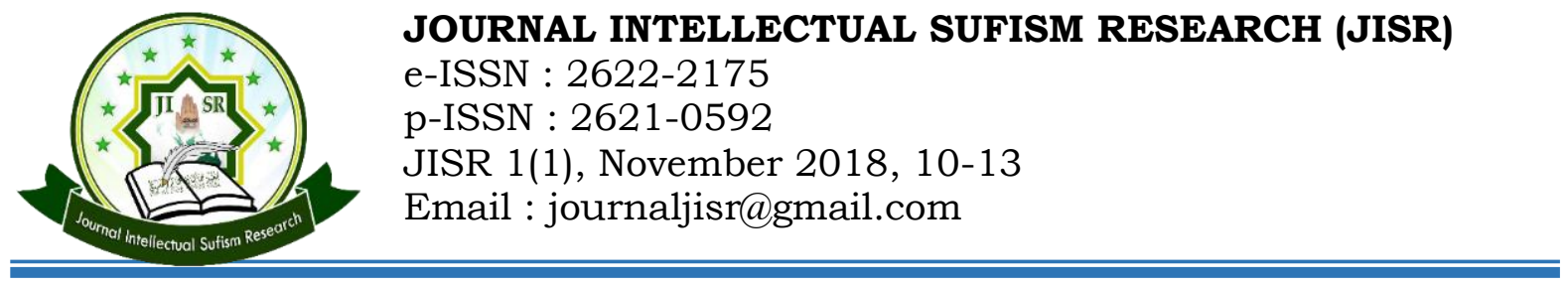

\title{
SUFISTIC EDUCATION, A URGENCY OF AGE MODERNITY
}

\author{
H Aliyah $^{1 *}$, Supriyadi ${ }^{2}$ \\ ${ }^{1}$ Science Education, Postgraduate, Surabaya State University \\ ${ }_{2}^{2}$ Islamic Studies Concentration of Sufism, Jagad Students' Islamic Boarding School Alimussirry \\ Surabaya \\ Email: himatulaliyah16070695042@mhs.unesa.ac.id
}

\begin{abstract}
The life of modern society is identical with deification of science and technology, ruling out an understanding of religion. Sufism invites its adherents to think and dhikr, to use their minds intellectually optimally for the sake of the people to keep their hearts together in remembering Allah in the recitation of dhikr. Sufistic Education or Sufism need to be returned, applied and developed in human life so as to create as true individuals.
\end{abstract}

Keywords: Sufism education, Sufism, modernity era

\section{INTRODUCION}

Ahlusunnah Wal jamaah (Aswaja) tradition allows its adherents to see things in a balanced and harmonious manner. Aswaja covers the aspects of aqidah (theology), Shari'a and Sufism (morality, ethics). The guidance of a group of Muslims who want the application of Islamic Shari'a in absolute terms often neglects the inner and ethical dimensions of Islam, namely the aspect of Sufism. In the view of aswaja, this neglect is considered to violate sunnatullah which requires humans to live in harmony and balance .

Sufism is an effort to train the soul with various activities that can free itself from the influence of world life, so as to create noble character and close to Allah SWT. In other words, Sufism is a field ofactivity related to spiritual mental development in order to always be close to God.

The scope of the meaning of Sufism is not just ethics, but also aesthetics, beauty. Sufism is not only trying to create people who live righteously, diligently worship, have good character, but also feel the beauty of life and the joy of worship. Sufism also seeks to answer the essential problem of why people must have good character. If ethics can give birth to a spirit of justice and the ability to respond to everything correctly, Sufism can foster meaning and value, and make the actions and lives of people more broad and rich. It is inversely proportional to the elegant concept of Sufism. Modernity of the times comes complete with all its problems. Various crisis befell human life ranging from social crises, structural crises, to spiritual crises. The morality crisis becomes the most visible thing. Revisited in mid-1997economic crisis hit Indonesian people are caused by weak ethics in national life. Weak ethics really provide opportunities for the rampant practice of corruption, collusion and nepotism (KKN) which then undermines the progress achieved previously. As the results of the PERC survey (Political and Economic Risk Consultacy) located in Hongkong in 2002 and 2006 explained that Indonesia ranked in 
the corruption score is the highest in Asia with a score of 8.16 (out of a total score of 10).

It is these various factors that require education to play a role, especially Sufism education or also called sufistic education. Sufistic education is expected to be a medium in delivering knowledge and moral improvement among the people so that it will encourage the ethical or moral development of students, so that people are created who not only master religion and general sciences, but also noble .

Based on the above conditions, this paper attempts to explore the urgency of sufistic education or Sufism education amid the modernity of the age with all its probabilities.

\section{METHOD}

This study uses a literature review to uncover ka $n$ how Sufism on the problematic relation

between education and life. Literatures used include books, articles, and trusted sites. By comparing various exposures from the literature, the author analyzes, identifies and reviews to produce a more objective view of the need for sufistic education to deal with the problems of the times.

\section{DISCUSSION}

\section{Sufism and Education}

Sufism as the study of ways and ways in which Muslims can be as close as possible to Allah SWT in order to obtain a direct relationship with Him, meaning how a person can truly be in His presence (Nasution, 1983). Ibrahim Basyuni classified sufism into 3 types which showed elements, namely: 1) Al-bidayah (stage of Sufism consciousness), 2) Al-mujahadah ( practical practice of Sufis who is a stage of hard struggle ); and sss3) $\mathrm{Al}$ Madzaqat (experience in terms of feeling ). Thus, the essence of Sufism is the awareness of the existence of communication and dialogue between the human spirit and the absolute reality (Allah) that can be obtained through several specific efforts.

Associated with the educational context, the basic educational goals are to develop the self-potential of students, both cognitive, affective, and psychomotor. In other languages, there are 3 intelligences in human beings; intellectual, emotional, and spiritual that must be developed through educational steps. The essence of Islamic education is actually a process that is always related to the values of vertical transcendence (ketauhidan). Therefore, the meaning of education is a combination keungg spirituan with cultural ulan. In the sense of putting forward a balance between intellectual, emotional and spiritual.

Islamic learning is divided into two aspects, namely exoteric (lahiriyah) and esoteric (inner) aspects. This esoteric aspect of Islam is what is called sufism. With the weak teaching of esoteric aspects of Islam so far also means that the teaching of Sufism in Islam is still lacking. Whereas should the teachings of Sufism be carried out in a balanced manner with the exoteric aspects of Islam. So that there will be balanced and perfect Muslim individuals, they will not only grow and develop to master Islam and general science, but will also be noble.

\section{Age Modernity}

Modernity is an adjective of modernization. Modernization is an inevitable process that occurs in all countries in the world, including developing countries. The purpose of modernization is the creation of humans and modern society.

Deliar Noer mentions the characteristics of modern society as follows: 1) Rational, that is, prioritizing the opinion of the mind rather than emotional opinions. Before doing the work always be considered first for the loss, and the work is logically considered beneficial; 2 ) Thinking for a more distant future, not only thinking about problems that are momentary, but always seen in the social damfurther. ; 3 ) 
Appreciate time, which is always seeing that time is something that is very valuable and needs to be used as well as possible; 4) Be open, ie willing to accept suggestions, input, both in the form of criticism, ideas and improvements wherever they come; and 5) Objective thinking, which is seeing everything from its functions and uses to society.

Ideally modern humans are humans who think logically and are able to use various technologies to improve the quality of human life. With intelligence and technological assistance, modern humans must be wiser and wiser, but in reality many people have lower human qualities than the progress of thinking and technology achieved. As a result of this imbalance, it causes a mental disorder.Unfortunately, the use of trapping tools and modern communication tools causes humans to live in global and desired influence by currents. Global information, even though human mental readiness individually or even ethnically is not the same

\section{Modernity Problems of the Age}

Modern life is synonymous with peng e deify science knowledge and technology, leaving aside religious understanding. They assume that science and technology will be able to improve the standard of lif $\mathrm{p}$ a n. Though not always as expected in pkan because of advances in the field of developing nologi tek in modern society will give two impacts to human life, which can have a positive impact and, on the other hand, it can also lead to negative effects.

In addition to the problems in the aspect of intellectual development, especially pen gmbangan science and toak nologi, in modern society experience a variety of problems in other aspects, such as in the political, religious pluralism musty, stale spiritual and ethical aspects.

In the last few decades it has been felt full of crises. Western critics point out that at least in the post-modern world there are five crises: 1) An identity crisis, in which humans

have lost their personality and form themselves. In this case, it will be easy to find the answer in Islamic da'wah ; 2) A legality crisis, where humans have begun to lose the determination of regulations for themselves and society.Islamic da'wah is full of teachings about life's guidance; 3) Penetration crisis, where humans have lost a lot of good influence for themselves and their communities, full of physical and mental pollution.Da'wah Islamiyah comes to clarify the human mind and filter its behavior, through ethical and responsible mental preparation;4) Crisis of participation, where humans have lost cooperation, are too individualistic. Islamic Da'wah is giving effective medicine; and 5) Distribution crisis, where humans are haunted by the absence of justice and equal distribution of income. Islamic Da'wah teaches justice in its entirety.

The same thing was expressed by Said Aqil Siraj (2006), in this modern era, various crises befall human life from social crisis, structural crisis, to spiritual crisis. And it all comes down to the question of the meaning of human life. Modernity with all technological advances and the rapid industrialization make people lose their orientation. Material wealth increasingly accumulates, but the soul experiences emptiness. Along with an increasingly modern orientation, lanyas work and material become the actualization of people's lives. The idea of the meaning of life is falling apart. As a result humans are like a machine. Everything is measured on the basis of material .

\section{The Role of Sufistic Education in Facing the Modernity of the Age}




Sufism has the role of releasing spiritual misery and emptiness to gain determination in seeking God. Sufism is also an educational method that guides people into total harmony and balance. True bawawuf means an education with emotional and spiritual intelligence. The point is learning to keep abreast of religious guidance, whether it is when faced with calamity, luck, the envy of others, the challenges of life, wealth, poverty, or in a state of self-control or development of self-potential. Great Sufis like Rabi'ah Al-Adawiyah, Al-Ghazali, etc. have set an example to the people how good education is. Among them proceed towards self and personal improvement which in turn will reach the peak of ma'rifatullah, namely the Khalik as the terminal end of human journey on the surface of the earth.

Some of Sufism seems to be able to make a positive contribution that can be practiced in modern society and the dap A $t$ is used as a solution to the community, as a spiritual bulwark in the face of modern problematikan. For this reason, in overcoming the problems of modern society, Sufism must be the most important alternative. The teachings of Sufism need to be applied in all aspects of modern human life, economic, social, political, cultural, and so on. By applying the teachings of Sufism proportionally and applying the principles of Islamic morality, it will manifest the main human personality capable of becoming a good and useful citizen and nation. Thus, based on the essential aspects of this mystical education, humans need to be returned to their "center of existence" or "spiritual center".Strengthening education based on the values of cohesion or alumni needs to be developed so as to affirm the authenticity of humanity which is always given a divine touch, giving birth to a kaffah, who thinks at the same time always dhikr .

\section{CONCLUSION}

Based on the description above, it can be concluded that: Sufistic education or Sufism needs to be returned, applied, and developed in human life that continues to move dynamically to help humans deal with the problems that occur, so that harmony and order are balanced in society, and personal a disgraceful person, who masters the general sciences, religious sciences, as well as noble, who always thinks and dhikr remembers his God .

\section{REFERENCES}

Malik, Halim . 2012. Individual Modernity. http://www.kompasiana.com/ unik/modernitas-individu accessed February 25, 2016.

Nasution, Aaron. 1983. Philosophy and Mistism in Islam. Jakarta: Bulan Bintang.

Nata, Abuddin. 2010. Sufism Morals. Jakarta: PT Raja Grafindo Persada.

Ni'am, Syamsun. 2013. Educational Institutions in Sufism. journal Kanz Philosophia, Volume 3, Number 2.

Noer, Deliar. 1987. Development in Indonesia. Jakarta: Mutiara.

Poerwadarminta, WJS 1991. General Indonesian Dictionary. Jakarta: Balai Pustaka.

Sayyid, Achmad. 2013. Sufistic Assessment in Learning Islamic Education . http://keyboardcakrawala.blogspot.co.id/2013/01/ approach- sufistikin-pelelaan.html accessed on Feb 24 2016

Siroj, Aqil Said. 2006. Sufism as social criticism. Jakarta: SAS Foundation.

Tebba, Sudirman. 2003. Positive Sufism. Jakarta: Prenda Media.

Umami, Syifa, et al, 2013. The Problems of Modern Society and the Importance of Sufism

Morals. http://umamisyifa.blogspot.co.id /2013/12/problematics-communitymodern-dan.html accessed on February 172016

Winarti, Sri. 2013. Application of Sufism in the

Modern

World. http://umamisyifa.blogspot.co.id/ 2013/12/problem-memunity-moderndan.html accessed February 172016 